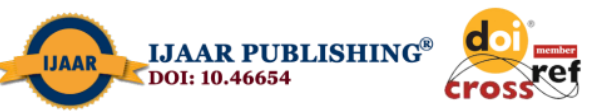

Research Journal of Management Practice | ISSN: 2782-7674

Vol. 1, Issue 5 (May, 2021) |www.ijaar.org

Journal DOI: www.doi.org/10.46654/RJMP

Article DOI: www.doi.org/10.46654/RJMP.1501

\section{THE IMPACT OF DEFENSIVE SILENCE ON \\ COLLABORATION AND CREATIVITY OF WORK TEAMS}

\author{
${ }^{1}$ Duru George Chukwudi \& ${ }^{2}$ Prof. B. C. Onuoha \\ Department of Management, University of Port Harcourt
}

Abstract

This study examined the extent to which defensive silence affects the collaboration and creativity of employees within the banking sector. For the study, self determination theory was adopted as the theoretical framework. The study focused on staff with full employment in deposit money banks in the South-South states of Akwa Ibom, Bayelsa, Cross River, Delta, and Rivers. Focus would be on Rivers, Bayelsa and Akwa Ibom. The choice of these three cities and states was informed by proximity to the researcher. Preliminary investigation shows that a total of one thousand, four hundred and forty-one (1441) management and subordinate staff are in the eighteen (18) selected deposit money banks. The determination of the sample size was done using the Krejcie and Morgan (1970) table and the result was 302. Multiple regression was used to test the null hypotheses. Our findings revealed a significant relationship between defensive silence and both collaboration and creativity. The study further recommended that organizations need to ensure that both managers and employees have the necessary support to be creative and understand how to use it in their particular job situation.
\end{abstract}

Keywords: Defensive, silence, collaboration, creativity, banks 
Journal DOI: www.doi.org/10.46654/RJMP

Article DOI: www.doi.org/10.46654/RJMP.1501

\section{Introduction}

Organizational Silence denotes circumstances where employees hold back potentially valuable information from the organization of which they are a part. Van Dyne et al. (2003) described silence as an employee's incentive to hold back or articulate proposals, information and views regarding work-associated developments. Silence is a communicative option that employees may choose to assume. Tangirala and Ramanujam (2008) assert that the silence could be deliberate or unintended; information can be consciously held back by employees. Organizational silence involves a collective belief among employees that speaking up is imprudent. Employees learn that when they disclose information about subjects or difficulties, the organization garners all the advantages while they bear the costs. The employees are unwilling to talk about the issues that can be understood erroneously by the managers and perceived as a threat. Nevertheless as Milliken (2000) observes they are not oblivious of the problems and they converse about it among themselves when they are alone only they are unable to speak the truth to their supervisors and they feel obliged to stay silent. Organizational silence is not an individual behaviour; it is multiplied all over the organization. In reality it involves a broad-spectrum mind-set of employees; still, it has consequences for new organization members. Talking is discarded by employees due to precedence of negative incidents by those who have been in the organization for many years. New entrants follow the instance of the experienced employees and decide to stay silent to avoid damage. Aktan (2006) observes that employees suppose that there is no prospect of change in the unwanted organizational situations and consequently repudiate taking action; lose their self-assurance and suffer inadequacy and powerlessness. Aylsworth (2008) affirms that instead of defiance, they concede and normalize the unwanted organizational conditions. Van Dyne et al. (2003) introduced three types of silence as - acquiescent silence, defensive silence, and pro-social silence. Acquiescent Silence involves keeping back important ideas, information, or opinions, because of resignation. It implies disengaged behaviour that is more passive than active and is motivated by resignation, obedience and accent to anything.

Defensive Silence is holding back important ideas, information, or opinions as a method of self- protection, arising from fear. It is deliberate and practical behaviour aimed at selfprotection from external threats. Van Dyne, et al. (2003) observes that contrary to Acquiescent Silence, it is more hands-on and entails consciousness and reflection of choices, added to a cognisant resolution to hold back ideas, information, and opinions as the best personal plan at the moment. Pinder and Harlos (2001) refer to quiescent silence as deliberate omission based on personal fear of the consequences of speaking up. It is motivated by selfprotection. Pro-social Silence entails withholding work-related ideas, information, or opinions with the aim of profiting other people or the organization arising from altruism or cooperative motives. Van Dyne, et al. (2003) affirms that it is optional behaviour based on consciousness and reflection on choices and the cognisant resolution to withhold ideas, information, and opinions. It is motivated by concern for others, being interested in others and creating opportunities for collaboration.

The attainment of work goals is critical for individual and organizational success (Kanter \& Brinkerhoff, 1981). The idea that task accomplishment satisfaction relates to affective states is consistent with affective events theory (Weiss \& Cropanzano, 1996). Weiss and Cropanzano developed affective events theory to explain how discrete work events provoke emotional reactions that influence subsequent behavior and attitudes. We contend that daily self-evaluations of one's task accomplishment represent affective events that influence 
employee emotions (Henkel \& Hinsz, 2004). Indeed, Basch and Fisher (2000) found that goal progress, goal achievement (or lack thereof), and task problems were retrospectively identified by individuals as affective events impacting daily emotions. Further, satisfaction with goal accomplishment has been implicated in theories of behavioral self-regulation (Carver \& Scheier, 1990). Thus, exploring how day-level satisfaction with task accomplishment relates to affect is an important next step in linking task performance with well-being.

Support for the idea that task accomplishment satisfaction impacts affect stems from previous work looking at goal accomplishment. Henkel and Hinsz (2004) found that individuals who attained their goals experienced more positive affect and less negative affect than did individuals who did not attain their goals. Similarly, Ilies and Judge (2005) found that performance feedback impacted subsequent affect (which predicted subsequent goals), with positive feedback resulting in positive affect and negative feedback resulting in negative affect. Though the results of these studies are suggestive, the potential generalizability of these findings is limited because the tasks used were laboratory based. Further, these studies did not assess satisfaction with task accomplishment, which prevents inferences about the links of task accomplishment satisfaction with affective reactions.

Addressing some of these limitations, Harris et al. (2003) utilized a 2-week daily diary study with a sample of 22 call center workers and found that daily goal attainment predicted daily affect (e.g., pleasurable affect, activated affect). Though this study utilized an applied sample in a naturalistic setting, it was limited in that (a) goal attainment pertained to abstract, needbased activities (e.g., good performance, being able to influence work) rather than concrete, occupation-specific work activities; (b) negative affect was not examined; (c) the level of satisfaction with attainment was not assessed; and (d) the role of person-level constructs was not considered. The current study addressed each of these limitations and took the additional step of distinguishing between tasks that are more or less central to the work role. As Peplau (1992) noted in regard to service providers, for example "The behavior of the nurse-as-aperson interacting with the patient-as-a-person has significant impact on the patient's wellbeing and the quality and outcome of nursing care". As such, nursing tasks that require more extensive nurse-patient interaction are more central to the occupation and may have greater implications for patient outcomes. We contend, in line with role-based identity theory (Ashforth, Kreiner, \& Fugate, 2000; Burke, 1991; Thoits, 1999), that the accomplishment of more central work tasks may have greater effects on employee well-being.

According to role-based identity theory, individuals have socially constructed definitions of their work roles, with some tasks being more directly important to a sense of role accomplishment and other tasks being more indirectly relevant. As Thoits has noted, sources of stress that implicate central aspects of an individual's self-concept should be more predictive of outcomes than those that affect less central features. Focusing specifically on nursing, Aiken et al. (2001) provided a descriptive look at the frequency with which nursing tasks were performed in a sample of 43,329 nurses working at 711 hospitals in five countries (United States, Canada, England, Scotland, and Germany). High percentages of nurses from each country reported having to frequently perform indirect care tasks that do not require nurse-patient interaction (e.g., charting, reviewing test results) as well as direct care tasks that require such interaction (e.g., comforting and/or talking with patients). Aiken et al. theorized that not completing direct care tasks could be detrimental to well-being. Building on Thoits's (1999) view of identity and the fact that nurses' caring interactions with patients 
Journal DOI: www.doi.org/10.46654/RJMP

Article DOI: $\underline{w w w . d o i . o r g / 10.46654 / R J M P .1501 ~}$

and their families constitute an essential feature of nursing practice (Bolton, 2000; Woodward, 1997), we propose that dissatisfaction with the completion of tasks associated with direct, rather than indirect, patient care would be experienced as more problematic. Though we expected that daily task accomplishment satisfaction would relate to changes in affect, it was not clear whether the effects would be the same for positive and negative affect or whether one affective response would be more strongly impacted. Goal attainment and task satisfaction have been linked to positive affective reactions (Locke \& Latham, 1990). However, research on the negativity bias (Ito, Larsen, Smith \& Cacioppo, 1998) and the asymmetry effect (Taylor, 1991) has shown that negative events "elicit more physiological, affective, cognitive, and behavioral activity and prompt more cognitive analysis than neutral or positive events" (Taylor, 1991, p. 67).

\section{Operational Framework}

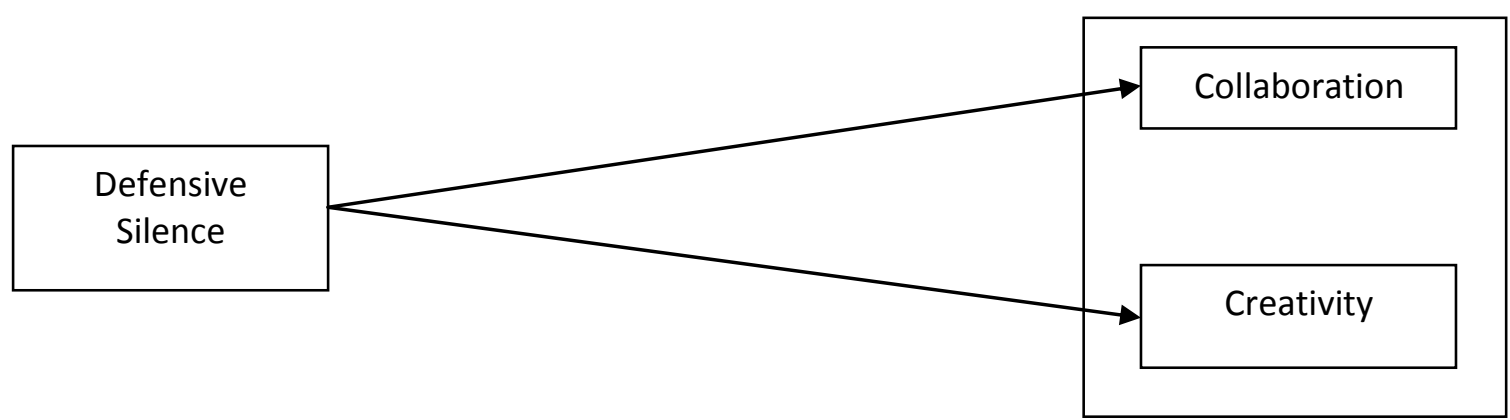

\section{Research Hypotheses}

$\mathrm{H}_{1}$ : Defensive silence does not relate with collaboration

$\mathrm{HO}_{2}$ : Defensive silence does not relate with creativity

\section{Theoretical Framework}

\section{Self-determination Theory}

The various conceptual models within traditional humanistic psychology share a central tenet: the fundamental value of the actualization of human potential. Both Abraham Maslow and Carl Rogers (Maslow, 1968; Rogers, 1961) developed optimistic theories that underscore the capacities, opportunities, and innate trajectory of human beings toward personal growth and psychological well-being. Self determination theory (SDT), developed more recently, has refined and advanced the optimistic perspective of traditional humanistic psychology by placing importance on the centrality of the self as a causal agent in human functioning. It stands in sharp contrast with deterministic and reductionist paradigms favored by contemporary psychological science, such as applied behavior analysis and cognitive neuroscience (Sheldon, Joiner, Pettit, \& Williams, 2003). However, research has shown that a 
Journal DOI: www.doi.org/10.46654/RJMP

Article DOI: www.doi.org/10.46654/RJMP.1501

positive life orientation in the absence of tangible accomplishment is linked to negative psychological, interpersonal, and real-world outcomes.

This paradox has been described in the literature as the tendency in contemporary society to emphasize positive illusions. Positive illusions appear to make life more satisfying in the short term, but in fact lead to negative consequences in the long run (Schneider, 2011). For example, the emphasis on cultivating self-esteem in students in educational settings, which originated with the broader self-esteem movement (Baumeister, Campbell, Krueger, \& Vohs, 2003) must be accompanied by real academic growth grounded in real academic achievement for psychologically beneficial outcomes to unfold. Of course, positive illusions can produce a sense of well-being in educational settings, but as Viktor Frankl (1969) noted, genuine and lasting well-being is the result of a "life well-lived". Thus, without real accomplishments there can be no eudaimonic well-being (Ryan \& Deci, 2001).

\section{Methodology}

Survey design was adopted for its descriptive nature, causal relations, and power to draw inferences from particular to general through the use of statistical control and appropriate test statistic. Specifically, explanatory and cross-sectional survey through the use of self-reported questionnaire was adopted; the choice of this design was informed by the nature of the phenomena of interest. For instance, change is best investigated in a given context defined as conditions and participants. The explanatory survey measures antecedent factors that cause change (cause-and-effect); thereby, leading to building and/or validating theories as well as predicting and controlling the phenomena under investigation. The cross-sectional study measures the snap short of opinions of management and subordinate staff of banks in the South-South region of Nigeria.

More specifically, we focused on staff with full employment in deposit money banks in the South-South states of Akwa Ibom, Bayelsa, Cross River, Delta, and Rivers. Focus would be on Rivers, Bayelsa and Akwa Ibom. The choice of these three cities and states was informed by proximity to the researcher. Preliminary investigation shows that a total of one thousand, four hundred and forty-one (1441) management and subordinate staff are in the eighteen (18) selected deposit money banks. The determination of the sample size was done using the Krejcie and Morgan (1970) table and the result was 302. Multiple regression was used to test the null hypotheses.

\section{Data Analyses and Findings}

\section{Hypothesis one}

$\mathrm{H} 0_{1}$. There is no significant relationship between defensive silence and collaboration.

Coefficients $^{\mathrm{a}}$

\begin{tabular}{|ll|l|l|l|l|l|}
\hline \multirow{2}{*}{ Model } & \multicolumn{2}{|l|}{ Unstandardized Coefficients } & \multicolumn{2}{l|}{$\begin{array}{l}\text { Standardized } \\
\text { Coefficients }\end{array}$} & \multirow{2}{*}{ Sig. } \\
\cline { 2 - 5 } & $\mathrm{B}$ & Std. Error & Beta & & \\
\hline \multirow{2}{*}{1} & (Constant) & 11.082 & .368 & & 30.130 & .000 \\
& Defensive silence & -.181 & .042 & -.188 & -4.344 & .000 \\
& Collaboration & -.828 & .032 & -1.106 & -25.494 & .000 \\
\hline
\end{tabular}

a. Dependent Variable: collaboration 
Journal DOI: www.doi.org/10.46654/RJMP

From the above table, the standardized coefficients of -0.188 for defensive silence shows a negative relationship between defensive silence and collaboration. The t-statistics value of 4.344 is seen to be greater than \pm 2 at a probability value of 0.000 which is less than the 0.05 significance level. This therefore leads to the rejection of the null hypothesis and acceptance of its alternate form that there is a significant relationship between defensive silence and collaboration.

\section{Hypothesis Two}

$\mathrm{HO}_{2}$. There is no significant relationship between defensive silence and creativity.

Coefficients $^{\mathrm{a}}$

\begin{tabular}{|ll|l|l|l|l|l|}
\hline \multirow{2}{*}{ Model } & \multicolumn{2}{|l|}{ Unstandardized Coefficients } & \multicolumn{2}{l|}{$\begin{array}{l}\text { Standardized } \\
\text { Coefficients }\end{array}$} & \multirow{2}{*}{ Sig. } \\
\cline { 3 - 6 } & & $\mathrm{B}$ & Std. Error & Beta & & \\
\hline \multirow{2}{*}{1} & .945 & .270 & & 3.498 & .001 \\
& (Constant) & -.411 & .031 & -.364 & -13.397 & .000 \\
& Defensive & -.560 & .024 & -.638 & -23.460 & .000 \\
\hline
\end{tabular}

a. Dependent Variable: Creativity

From the above table, the standardized coefficients of 0.638 for defensive silence shows an adverse relationship between defensive silence and collaboration. The t-statistics value of 23.460 is seen to be greater than \pm 2 at a probability value of 0.000 which is less than the 0.05 significance level. This therefore leads to the rejection of the null hypothesis and acceptance of its alternate form that there is a significant relationship between defensive silence and creativity.

\section{Conclusion}

Defensive silence shows a negative and significant relationship with collaboration of employees. This shows that an increase in Defensive silence of employees would reduce and lead to a corresponding decrease in the workplace collaboration of employees. Acquiescence is an indicator of the lack of organizational support manager support and preparedness. It can be identified that; Lack of organizational support is well aligned with lower levels of perceived organizational support, as would be expected, and with lower levels of manager creative-supportive behavior. Conversely, this interrupter was not nearly as well aligned with lower levels of all the employee collaboration characteristics. Lack of manager support to prepare the employee to do collaborative work is well aligned with lower levels of both manager factors of expectations for collaborative work and supportive behavior. Lack of preparation to collaborate was similarly aligned with all the factors in the model, but only at very minimal levels. Lack of skill to complete collaborative tasks is moderately well aligned with lower levels of collaboration. This findings tallies with those of previous literature that have clearly discussed the downside of employee productivity such as Sharma and Sharma (2014), Cato and Gordon (2009) Morales et al., (2001) and Obdulio (2014).

Defensive silence also displays a negative and significant relationship with the creativity of employees. This shows that, when leaders display Defensive silence, this leads to lower workplace creativity of employees. Gephart-Kish et al. (2009) suggested that defensive silence should be categorized with regard to the level of fear experienced by the employee (low-high) and to the amount of time employee has to take action (short-long). This is the result of what has been called the wisdom of crowds: increased capacity for achieving various 
types of performance made possible by the interaction of team members (Salas, Rosen, Burke $\&$ Goodwin, 2009). Thus, the success of organizations and the overall production of knowledge depend to a large extent on the effectiveness of teams (Wuchty, Jones \& Uzzi, 2007). This finding results from employee fears. For example, an employee may experience a low level of fear when he reflects on going to talk to the boss about suggestions for improvement. In this situation, the employee has time enough to deliberately and consciously determine the costs and benefits of speaking up (in case he wants to), to consult others and to evaluate different strategies instead of speaking up (Kish-Gephart et al., 2009). This therefore affects their creativity. For example, for an individual who developed fear of talking openly to his leader due to a past negative experience, he is unlikely to check again if there are still threats by speaking up (contributing, that way, for the climate of silence) (Kish-Gephart et al., 2009).

\section{Recommendations}

The study recommends that board of trustees of deposit money banks do the following

i. Have the manager work on establishing a trusting relationship beginning in the creativity preparation phase through how they assist the employee in preparing and then throughout the execution phase by playing close attention to the tone and content of their interactions with the employee.

ii. Help employees to interpret and apply the organizational expectations and support features to their own job by having them articulate what they expect creatively, what they think the creative expectations and opportunities are of their job and how they believe it will add the most value.

iii. Individually tailor the organizational supports that the employee most needs based on their reported creative preparation needs. Individual needs could vary from learning how they can establish more autonomy, establishing parameters for more dedicated creative work time or coaching on how to balance work priorities. 


\section{References}

Ahmad, A., \& Omar, Z. (2014). Reducing Deviant Behavior through Workplace Spirituality and Job Satisfaction. Asian Social Science, 10(19), 107-112.

Aktaş, H. \& Şimşek, E. (2015). The role of perceptions of job satisfaction and emotional burnout in individuals' organizational silence attitudes. International Journal of Management Economics and Business, 11(24), 205-230.

Alexander, L.D. (1985) Successfully Implementing Strategic Decisions, Long Range Planning,91-97.

Amabile, T. M. (1988). A model of creativity and innovation in organizations. Research in Organizational Behavior, 10, 123.

Amabile, T. M., Conti, R., Coon, H., Lazenby, J, \& Herron, M. (1996). Assessing the work environment for creativity. Academy of Management Journal, 39(5), 11541184.

Boyatzis, R.E (1982)The Competent Manager, New York: John Wiley.

Brinsfield, C. T. (2009). Employee silence: Investigation of dimensionality, development of measures, and examination of related factors (Doctoral dissertation, The Ohio State University).

Brinsfield, C. T. (2013). Employee silence motives: investigation of dimensionality and development of measures. Journal of Organizational Behavior, 34(5), 671697.

Broussard, S. C., \& Garrison, M. E. B. (2004). The relationship between classroommotivation and academic achievement in elementary school-aged children. Family and Consumer Sciences Research Journal, 33(2), 106-120.

Brown,M.E., Trevin'o, L.K, \& Harrison, D (2005). Ethical Leadership: A Social Learning Perspective for Construct Development and Testing, Organizational Behavior and Human Decision Processes, 97, 117-134.

Brown,M.E., Trevin'o, L.K. (2006) Ethical Leadership: A Review and Future Directions, The Leadership Quarterly; 2006, 17, 595- 616.

Çakıc1, A. (2007). A research on issues, causes and perceptional results of silence at organizations. Cukurova University Journal of Graduate School of Social Sciences, 17(1), 117-134.

Cakinberk, A.K., Dede, N.P., \& Yilmaz, G. (2014). Relationship between organizational trust and organizational silence: an example of public university. Journal of Economics Finance and Accounting, 1(2), 91-105. 
Carmeli, A., \& Schaubroeck, J. (2007). The influence of leaders' and other referents' normative expectations on individual involvement in creative work. Leadership Quarterly, 18(1), 35-48.

Carmeli, A., Reiter-Palmon, R., \& Ziv, E. (2010). Inclusive Leadership and Employee Involvement in Creative Tasks in the Workplace: The Mediating Role of Psychological Safety. Creativity Research Journal, 22(3), 250-260.

Carroll, S.J.Jr.,Gillen, D.J (1987). Are the Classical Management Functions Useful in Describing Managerial Work?, Academy of Management Review, 12, 38-51.

Case, R. (2005). Moving critical thinking to the main stage. Education Canada, 45(2):45-49.

Çavuşoğlu, G., Ünver, Ş., Doğan, E., İslamoğlu, İ., \& Özdemir, S. (2015). Comparison of the burnout levels of academics in the faculty of sports sciences and other faculties. The Journal of Sport Management and Information Sciences, 10(1), 4-13.

Drazin, R., Glynn, M. A., \& Kazanjian, R. K. (1999). Multilevel theorizing about creativity in organizations: A sensemaking perspective. Academy of Management Review, 24(2), 286-307.

Durak, İ. (2014). Relationships between organizational silence and demographics, institutional factors: a study on academic staff]. Atatürk University Journal of Economics and Administrative Sciences, 28(2), 89-108.

Earle, B.H., Madek, G.A. (2007) The Mirage of Whistleblower Protection under Sarbanes-Oxley: A Proposal for Change, American Business Law Journal, 44, 154.

Ebrahimi Mehrabani, S. and Azmi Mohamad, N. (2015). New approach to leadership skills development (developing a model and measure). Journal of Mgmt Development, 34(7), 821-853.

Edmondson, A. (1999). Psychological safety and learning behavior in work teams. Administrative science quarterly, 44(2), 350-383.

Edmondson, A. C., \& Lei, Z. (2014). Psychological safety: The history, renaissance, and future of an interpersonal construct. Annual Review of Organizational Psychology and Organizational Behavior. 1(1), 23-43.

Edmondson, A. C., (2003). Psychological Safety, Trust, and Learning in Organizations: A Group-level Lens. 1-43

Edwards, M. S., Ashkanasy, N. M., \& Gardner, J. (2009). Deciding to speak up or to remain silent following observed wrongdoing: The role of discrete emotions and 
climate of silence. In Greenberg, J., \& Edwards, M. S. (Eds.). (2009). Voice and silence in organizations. Emerald Group Publishing, 83-111.

Ehtiyar, R., \& Yanardağ, M. (2008). Organizational silence: A survey on employees working in a chain hotel. Tourism and Hospitality Management, 14(1), 51-68.

Ek, Å., Runefors, M., \& Borell, J. (2014). Relationships between safety culture aspects-A work process to enable interpretation. Marine Policy, 44, 179-186.

Ennis, R. H. (1985). A logical basis for measuring critical thinking skills. Educational

Erkutlu, H. (2008). The impact of transformational leadership on organizational and leadership effectiveness. Journal of Mgmt Development, 27(7), 708-726.

Fleishman, E.A., Mumford, M.D., Zaccaro, S.J., Levin, K.Y., Korotkin, A.L., \& Hein, M.B. (2008) Taxonomic Efforts in the Description of Leader Behavior: A Synthesis and Functional Interpretation, Leadership Quarterly, 2, 245-287.

Ford, C. M. (1996). A theory of individual creativity action in multiple social domains. Academy of Management Review, 21(4), 1112-1142.

Fuentes, M. Mar, Carlos A. Albacete-Saez-F. Javier Llorens-Montes (2004) The Impact Of Environmental Characteristics On TQM Principles And Organizational Performance, Omega The Int. Journal Of Management Science; . Goldstein, I.L. Training and Development in Organizations, Monterey, CA

George, J. M., \& Jing Zhou. (2007). Dual tuning in a supportive context: joint contributions of positive mood, negative mood, and supervisory behaviors to employee creativity. Academy of Management Journal, 50(3), 605-622.

Gong, Y., Cheung, S. Y., Wang, M., \& Huang, J. C. (2012). Unfolding the proactive process for creativity integration of the employee proactivity,information exchange, and psychological safety perspectives. Journal of Management, 38(5), 1611-1633.

Kark, R., \& Carmeli, A. (2009). Alive and creating: The mediating role of vitality and aliveness in the relationship between psychological safety and creative work involvement. Journal of Organizational Behavior, 30(6), 785-804.

Kim, H., Yukl, G (1995). Relationships of Self-Reported and Subordinate-Reported Leadership Behaviors to Managerial Effectiveness and Advancement, Leadership Quarterly, 6, 361-377.

Kirkman, B.L., B. Rosen (1999). Beyond Self-Management: Antecedents and Consequences of Team Empowerment, Academy of Management Journal,42 (1),58-74.

Kish-Gephart, J. J., Detert, J. R., Treviño, L. K., \& Edmondson, A. C. (2009). Silenced by fear: The nature, sources, and consequences of fear at work. Research in organizational behavior, 29, 163-193. 
Kocaeli, Turkey. Şimşek, E., \& Aktaş, H. (2014). The interactions of organizational silence with personality and life satisfaction: A research on public sector. Anadolu University Journal of Social Sciences, 14(2), 121-136.

Komaki, J (1986). Toward Effective Supervision: An operant Analysis and Comparison of Managers at Work, Journal of Applied Psychology, 71,270-278.

Konakay, G. (2013). A research about the relationship between emotional intelligence factors and burnout factors of academicians: Case of Kocaeli University. Eylül University Journal of Graduate School of Social Sciences, 15(1), 121-144.

Korkmaz, O. \& Aydemir, S. (2015). A research on determining the relationship between organisational silence and organisational citizenship behaviour. Yönetim ve Ekonomi Araştırmaları Dergisi, 13(2), 140-165.

Köse, E. K. (2014). Relationships between teachers' organizational commitment and organizational silence in disadvantaged schools. International Journal of Turkish Educational Sciences, 2(2), 28-36.

Küçüksüleymanoğlu, R. (2007). Burnout levels of education faculty teaching staff. Eurasian Journal of Educational Research, 28, 101-112.

Lackritz, J.R. (2004). Exploring burnout among university faculty: Incidence, performance, and demographic issues. Teaching and Teacher Education, 20(7), 713-729.

Leadership, 43(2), 44-48.

LePine, J. A., \& Van Dyne, L. (1998). Predicting voice behavior in work groups. Journal of Applied Psychology, 83(6), 853-868.

LePine, J. A., Van Dyne, L (2001). Voice and Cooperative Behavior as Contrasting forms of Contextual Performance: Evidence of Differential Relationships with Big Five Personality Characteristics and Cognitive Ability, Journal of Applied Psychology, 86, 326-336.

Morrison, E. W. (2014). Employee voice and silence. The Annual Review of Organizational Psychology and Organizational Behavior, 1(1),173-197.

Morrison, E. W., \& Milliken, F. J. (2000). Organizational silence: A barrier to change and development in a pluralistic world. Academy of Management review, 25(4),706-725.

Morrison, E.W., \& Milliken, F.J. (2000). Organizational silence: a barrier to change and development in a pluralistic world. Academy of Management Review, 25(4), 706-725. 
Morrison, E.W., \& Milliken, F.J. (2003). Speaking up, remaining silent: the dynamics of voice and silence in organizations. Journal of Management Studies, 40(6), $1353-1358$.

Park, C., \& Keil, M. (2009). Organizational silence and whistle-blowing on IT projects: An integrated model. Decision Sciences, 40(4), 901-918.

Pinder, C. C., \& Harlos, K. P. (2001). Employee silence: quiescence and acquiescence as responses to perceived injustice. Research in Personnel and Human Resources Management, 20, 331-370.

Pinder, C. C., \& Harlos, K. P. (2001). Employee silence: quiescence and acquiescence as responses to perceived injustice. Research in personnel and human resources management, 20, 331-370.

Premeaux, S.F., \& Bedeian, A.G. (2003). Breaking the silence: The moderating effects of self-monitoring in predicting speaking up in the workplace. Journal of Management Studies, 40(6), 1537-1562.

Tierney, P. \& Farmer, S. M. (2011). Creative self-efficacy development and creative performance over time. Journal of Applied Psychology, 96(2), 277-293.

Toker, B. (2011). Burnout among university academicians: an empirical study on the universities of Turkey. Doğuş University Journal, 12(1), 114-127.

Tülübaş, T., \& Celep, C. (2014). Causes of Faculty Members' Silence University Journal of Education, 29(1), 280-297.

Tümkaya, S. (2000). Improving the scale of academic burnout. Hacettepe University Journal of Education Faculty, 19, 128-133.

Ülker, F., \& Kanten, P. (2009). A Research on silence climate, employee silence, and organizational commitment relationship. Journal of Aksaray University Faculty of Economics and Administrative Sciences, 1(2), 111-126.

Van Dyne, L., Ang, S., \& Botero, I. C. (2003). Conceptualizing Employee Silence and Employee Voice as Multidimensional Constructs. Journal of Management Studies, 40(6),1359-1392.

Van Dyne, L., Ang, S., \& Botero, I.C. (2003). Conceptualizing employee silence and employee voice as multidimensional constructs. Journal of Management Studies, 40(6), 1359-1392.

Watts, J., \& Robertson, N. (2011). Burnout in university teaching staff: a systematic literature review. Educational Research, 53(1), 33-50.

Woodman, R. W., Sawyer, J. E., \& Griffin, R. W. (1993). Toward a theory of organizational creativity. Academy of Management Review, 18(2), 293-321. 
Yaman, E., \& Ruçlar, K. (2014). Organizational silence in universities as the predictor of organizational culture. Journal of Higher Education \& Science, 4(1), 36-50.

Zamini, S., \& Barzegary, L. (2011). The relationship between organizational culture and job burnout among the professors and employees in the University of Tabriz. Procedia-Social and Behavioral Sciences, 30, 1964-1968.

Zhang, X. \& Bartol, K. M. (2010). Linking empowering leadership and employee creativity: The influence of psychological empowerment, intrinsic motivation and creative process engagement. Academy of Management Journal, 53(1), 107128. 